\title{
Proteomic analysis of the wing imaginal discs of Drosophila melanogaster
}

\author{
Jana Alonso and Juan F. Santarén \\ Centro de Biología Molecular "Severo Ochoa", CSIC-UAM, Universidad Autónoma de Madrid, Madrid, Spain
}

We have combined high-resolution two-dimensional (2-D) gel electrophoresis and mass spectrometry with the aim of identifying proteins represented in the 2-D gel database of the wing imaginal discs of Drosophila melanogaster. First, we obtained a high-resolution 2-D gel pattern of $\left[{ }^{35} \mathrm{~S}\right]$ methionine $+\left[{ }^{35} \mathrm{~S}\right]$ cysteine-labeled polypeptides of Schneider cells, a permanent cell line of Drosophila embryonic origin, and compared it with the standard pattern of polypeptides of the wing imaginal disc. These studies reveal qualitative and quantitative differences between the two samples, but have more than 600 polypeptides in common. Second, we carried out preparative 2-D polyacrylamide gel electrophoresis using Schneider cells mixed with radioactively labeled wing imaginal discs in order to isolate some of the shared polypeptides and characterize them by matrix-assisted laser desorption/ionization-time of flight MALDI-TOF analysis. Using this strategy we identified 100 shared proteins represented in the database, and in each case confirmed their identity by MALDI-TOF/TOF analysis.

Keywords:

Drosophila / Matrix-assisted laser desorption/ionization-time of flight / Two-dimensional gels

\section{Introduction}

The generation of form in biological systems remains a challenging problem. Since the pioneering studies of Thomas H. Morgan and his coworkers begun in 1908, Drosophila melanogaster, has constituted one of the most powerful developmental model systems. The most important of its advantages are: ease of culturing, short generation time, small genome (about $1.6 \times 10^{8}$ base pairs of DNA per haploid genome, now fully sequenced), low chromosome number ( $n$ $=4$ ), presence of polytene chromosomes, and 90 years of accumulated genetic knowledge.

The structures on the surface of the adult Drosophila fly (such as wings, legs and antennae) are ideal for investigating the processes underlying morphogenesis. These structures are not formed from differentiated larval cells but rather from

Correspondence: Dr. Juan F. Santarén, Centro de Biología Molecular "Severo Ochoa", Facultad de Ciencias. Universidad Autónoma, Cantoblanco, E-28049 Madrid, Spain

E-mail: jfsantaren@cbm.uam.es

Fax: +34-1-4974799 small groups of proliferating but relatively undifferentiated cells called imaginal discs [1]. These provide a favorable system for analyzing the mechanisms controlling developmental cell proliferation and the genetic control of pattern, because of the separation in time between cell proliferation and differentiation, and the facility with which controlling genes can be identified and characterized. The 19 imaginal discs ( 9 pairs and 1 fused genital discs) are set aside very early in embryogenesis, and each is committed to a particular developmental pathway (e.g., left wing or right wing, left eye or right eye, etc.). The imaginal discs remain in a relatively undifferentiated state near the surface of the larvae until changing hormonal levels during pupation cause them to differentiate and undergo morphogenesis [2]. Detailed fate maps have been established for the different imaginal discs [3].

Imaginal discs have a simple histological structure consisting mainly of a single layer of cells forming a sac, connected to the larval epidermis by a stalk. The cells of the imaginal discs divide continuously during larval development. For example, the wing imaginal discs develop from a few cells until, at maturity, they contain about 50000 cells [4]. At metamorphosis, the discs evaginate, expand, and replace 
the larval epidermis, which undergoes programmed death. Thus the control of cell multiplication can be studied in the absence of complications due to simultaneous overt differentiation such as occurs in most vertebrate tissues.

We use 2-DE to analyze aspects of the development, morphogenesis and genetic variation of the wing imaginal disc of Drosophila [5]. Improvements in separation, as well as in labeling technique, have made it possible to resolve more than a thousand $\left[{ }^{35} \mathrm{~S}\right]$ methionine $+\left[{ }^{35} \mathrm{~S}\right]$ cysteine-labeled polypeptides from a single imaginal disc. We have constructed a quantitative protein database used as reference to detect changes in gene expression related to tissue type [6], stage of development [7], or genetic lesion [8]. However, the key to interpreting the data obtained by such analysis is the ability to identify (and characterize) the proteins of interest.

Since the amount of protein derived from wing imaginal discs is very limited, we have turned to the permanent Schneider cell line that was derived from Drosophila embryos. The goals of the experiments reported here were twofold: first to compare the pattern of proteins synthesized in wing imaginal discs and in Schneider cells; second, to explore the possibility of using proteins from the Schneider cells, purified via a limited number of preparative 2-D gels, to identify the corresponding proteins in wing imaginal discs. For this purpose we have started a systematic MALDI-TOF analysis that has permitted us to identify many proteins, some already known, others novel. We present the analysis of one hundred such proteins in this study.

\section{Materials and methods}

\subsection{Fly strains and cell culture}

Laboratory stocks of wild-type D. melanogaster (strain Vallecas Spain) were used.

We used the established cell line designated Schneider, of $D$. melanogaster. The cells were grown in bottles $\left(25 \mathrm{~cm}^{2}\right)$ in $20 \mathrm{~mL}$ of M3 medium supplemented with 5\% foetal bovine serum. For labeling, they were incubated for $120 \mathrm{~min}$ in $300 \mu \mathrm{L}$ of methionine- and cysteine-free medium with $300 \mu \mathrm{Ci}\left[{ }^{35} \mathrm{~S}\right]$ methionine $+\left[{ }^{35} \mathrm{~S}\right]$ cysteine (SJQ 0079; Amersham, Little Chalfont, UK). At the end of the labeling period, the medium was removed and the cells were resuspended in $100 \mu \mathrm{L}$ of lysis buffer and stored at $-70^{\circ} \mathrm{C}$.

\subsection{Sample preparation}

Imaginal discs were dissected from mature larvae (about 0$4 \mathrm{~h}$ before puparium formation) using a fibre optic light source to prevent heating of the tissue. Dissections was carried out in buffered Ringer's solution (10 mm Trizma base; $95 \mathrm{~mm} \mathrm{NaCl} ; 3 \mathrm{~mm} \mathrm{CaCl}_{2} ; 3 \mathrm{~mm} \mathrm{KCl}$, adjusted to $\mathrm{pH} 7.0$ ) freshly made up and filtered through a $0.22 \mu \mathrm{m}$ filter. As a rule we used 10 imaginal discs in each labeling experiment. The dissected discs were placed in $100 \mu \mathrm{L}$ of buffered Ring- er's solution in a well of a Microtest II tissue culture plate (Falcon No 3042; Becton Dickinson, France) and incubated for $60 \mathrm{~min}$ in $80 \mu \mathrm{L}$ of Ringer's solution containing $80 \mu \mathrm{Ci}$ of $\left.{ }^{35} \mathrm{~S}\right]$ methionine $\left.+{ }^{35} \mathrm{~S}\right]$ cysteine at $25^{\circ} \mathrm{C}$. Following incubation, the medium was removed and the discs resuspended in $100 \mu \mathrm{L}$ of lysis buffer.

\subsection{Two-dimensional gel electrophoresis}

Analytical 2-DE was performed as described by O'Farrell [9, 10] with some modifications [11]. Briefly, the first dimension for resolving acidic proteins (IEF) was performed on $230 \times 2.3 \mathrm{~mm} \mathrm{4 \%} \mathrm{w} / \mathrm{v}$ polyacrylamide gels containing $2 \%$ carrier ampholytes $(1.6 \% \mathrm{pH} 5-7 ; 0.4 \%, \mathrm{pH} 3.5-10)$ at $1200 \mathrm{~V}$ for $20 \mathrm{~h}$. Basic proteins (NEPHGE) were resolved on $150 \times 2.3 \mathrm{~mm} 4 \% \mathrm{w} / \mathrm{v}$ polyacrylamide gels containing $2 \%$ carrier ampholytes (1\% pH 7-9; $1 \% \mathrm{pH} 8-9.5)$ at $400 \mathrm{~V}$ for $4.5 \mathrm{~h}$. The second dimension employed a $15 \%$ polyacrylamide gel $(24 \times 24 \mathrm{~cm})$ run overnight at $18^{\circ} \mathrm{C}$. The gels were processed for fluorography [12], dried, and exposed at $-70^{\circ} \mathrm{C}$ for varying periods $(4,24,96$ and $240 \mathrm{~h})$. Approximately $10^{6}$ TCA-precipitable cpm $\quad\left[{ }^{35} \mathrm{~S}\right]$ methionine + $\left[{ }^{35} \mathrm{~S}\right]$ cysteine were routinely applied to each gel. For preparative gels we used proteins prepared from $2 \mathrm{~mL}$ of Schneider cultures. The cell suspension was centrifuged and the cells were sonicated, treated with DNase and RNase [13], and passed several times through a narrow gauge needle. The sample was then lyophilized and resuspended in $2 \mathrm{~mL}$ of lysis buffer. Gels were stained with Coomassie Brilliant Blue and silver nitrate.

\subsection{Computer analysis of 2-D patterns}

The fluorograms were digitized at $176 \times 176 \mu \mathrm{m}$ resolution with a GS-800 calibrated densitometer Bio-Rad, and the resulting 2-D images merged and analyzed with PDQUEST ${ }^{\mathrm{TM}}$ software (V. 5.1; Bio-Rad).

\subsection{In-gel digestion}

Coomassie- or silver-stained protein spots were excised and digested with trypsin (Promega, Madison, WI, CA, USA). After washing three times for $40 \mathrm{~min}$ with $100 \mu \mathrm{L} 50 \mathrm{~m} \mathrm{M}$ ammonium bicarbonate and 50\% methanol, the gel pieces were dried and swollen in digestion buffer $(20 \mathrm{~m} \mathrm{M}$ ammonium bicarbonate and $40 \mathrm{ng} / \mu \mathrm{L}$ trypsin), and incubated at $37^{\circ} \mathrm{C}$ for $16 \mathrm{~h}$. Peptides were extracted twice by $20 \mathrm{~min}$ incubation in $35 \mu \mathrm{L}$ of $50 \%$ ACN in $0.1 \%$ TFA. The resulting peptide extracts were pooled, concentrated in a vacuum centrifuge and stored at $-20^{\circ} \mathrm{C}$.

\subsection{Mass spectrometry analysis}

Dried samples were dissolved in $10 \mu \mathrm{L}$ of $30 \% \mathrm{ACN}$ and $0.1 \%$ TFA. Equal volumes $(0.5 \mu \mathrm{L})$ of peptide and matrix solution were mixed and crystallized on the sample plate. 
The matrix solution consisted of $3 \mathrm{mg}$ CHCA dissolved in $1 \mathrm{~mL}$ of a solution containing 50\% ACN and $0.1 \%$ TFA. Peptides were analyzed with the Applied Biosystems 4700 proteomics analyzer (Applied Biosystems, Framingham, MA, USA) with TOF/TOF ion optics. MS spectra were obtained in reflectron mode using an acceleration voltage of $1 \mathrm{kV}$. Desorption and ionization was performed with an $\mathrm{Nd}$ :YAG laser operating at $355 \mathrm{~nm}$, and the final mass spectrum was produced by averaging 3600 laser shots. The products of trypsin autodigestion were used for internal calibration. All MS/MS sequencing analyses were performed using the same equipment.

\subsection{Protein identification using the Drosophila database}

The first step in protein identification consisted of mass fingerprinting. The monoisotopic peptide mass fingerprinting data obtained from MALDI-TOF were then used to search for candidates in the Swiss-Prot/TrEMBL nonredundant protein database (http://us.expasy.org/tools/peptident.html).

\section{Results}

\subsection{General pattern of protein synthesis in Drosophila wing imaginal discs}

Figure 1A shows a wing imaginal disc of a wild-type third instar larvae of D. melanogaster (strain Vallecas) after dissection. Extensive studies of transplantation of imaginal disc fragments have shown that much of the pattering information needed to make the adult appendages has been elaborated in the disc by the end of the third larval instar; given regions of the disc reproducibly develop into particular parts of the adult appendage [14]. These studies have given rise to fate maps in which the spatial pattern of the adult appendages can be projected back onto the disc. Figure $1 \mathrm{~B}$ and $1 \mathrm{C}$ are fate maps of the wing imaginal disc, and Fig. 1D representative fluorograms (after $96 \mathrm{~h}$ of exposure) of 2-D gel of acidic and basic polypeptides from wing imaginal discs of mature larvae. For quantification, four different exposures of the gels were merged and analyzed by computer with the PDQUEST ${ }^{\mathrm{TM}}$ system, and each polypeptide was assigned a number in the database. In this way we compiled a database of $1492\left[{ }^{35} \mathrm{~S}\right]$ methionine $+\left[{ }^{35} \mathrm{~S}\right]$ cysteine labeled polypeptides (1226 acidic, IEF and 266 basic, NEPHGE). This constitutes our reference wing imaginal disc database.

\subsection{The protein pattern of Schneider cells}

Cultures of Schneider cells were labeled with $\left[{ }^{35} \mathrm{~S}\right]$ methionine $+\left[{ }^{35} \mathrm{~S}\right]$ cysteine for $2 \mathrm{~h}$ as described in Section 2.1. Polypeptides were separated on 2-D gels and analyzed with the
PDQUEST $^{\mathrm{TM}}$ software. A total of 824 polypeptides (608 acidic (IEF) and 216 basic (NEPHGE)) were identified, numbered and quantified as described in Section 3.1 for wing imaginal discs. We compared the Schneider 2-D pattern with our wing imaginal discs database and also ran samples containing a mixture of wing imaginal discs and Schneider cells. From these comparisons we concluded that the two systems have 634 polypeptides in common (461 IEF and 173 NEPHGE), and 190 polypeptides (147 IEF and 43 NEPHGE) were detected only in the Schneider cells. Although it is beyond the scope of this study to give a detailed comparative analysis of the two systems, it should be emphasized that there were appreciable differences in the levels of some of the shared polypeptides. Three hundred and sixty-three polypeptides (269 IEF and 94 NEPHGE) were expressed at similar levels in the two systems, whereas 197 polypeptides (152 IEF and 45 NEPHGE) were more highly expressed (at least two-fold) in the Schneider cells, and 74 polypeptides (40 IEF and 34 NEPHGE) in the discs. The shared polypeptides were of most interest to us, and Fig. 2 reproduces a small region of the IEF gels of wing imaginal discs (Fig. 2A) and Schneider cells (Fig. 2B) in which it is possible to see some of the shared polypeptides.

\subsection{Isolation of proteins for MALDI-TOF}

We took advantage of the shared proteins to isolate sufficient amounts of some of them to perform MALDI-TOF analysis of their tryptic peptides. After calibration with Coomassie blue stained 2-D gels, we ran preparative gels with precise amounts of polypeptides from the Schneider cells together with small amounts of $\left[{ }^{35} \mathrm{~S}\right]$-labeled polypeptides from wing imaginal discs. The gels were stained with Coomassie or silver nitrate, dried and exposed to X-ray film. The autoradiograms displayed only spots derived from the wing imaginal discs, but large amounts of comigrating unlabeled proteins derived from the cell line. We then ran new preparative 2-D gels and after staining picked some of these spots and subjected them to in-gel digestion with trypsin followed by MALDI-TOF analysis. We were able to identify 100 spots from the preparative gels (81 acidic and 19 basic) in the database. In all the cases analyzed we could confirm the information obtained from the peptide mass fingerprinting by MS/MS using MALDITOF/TOF. A total of $417 \mathrm{MS} / \mathrm{MS}$ spectra were analyzed. All the wing imaginal discs proteins identified in this study are listed in Tables 1 and 2 ordered by SSP number. Molecular weight, $\mathrm{pI}$, names, identified sequence tags, abundance relative and Flybase accession numbers are also included. Figure 3A shows, as an example, the MALDITOF spectrum of the tryptic digest of acidic polypeptide SSP 3303 identified as enolase (EC 4.2.1.11) and Fig. 3B reproduces a detail of the fragmentation spectrum of peak 1764.91 corresponding to polypeptide AAVPSGASTGVHEALELR. 

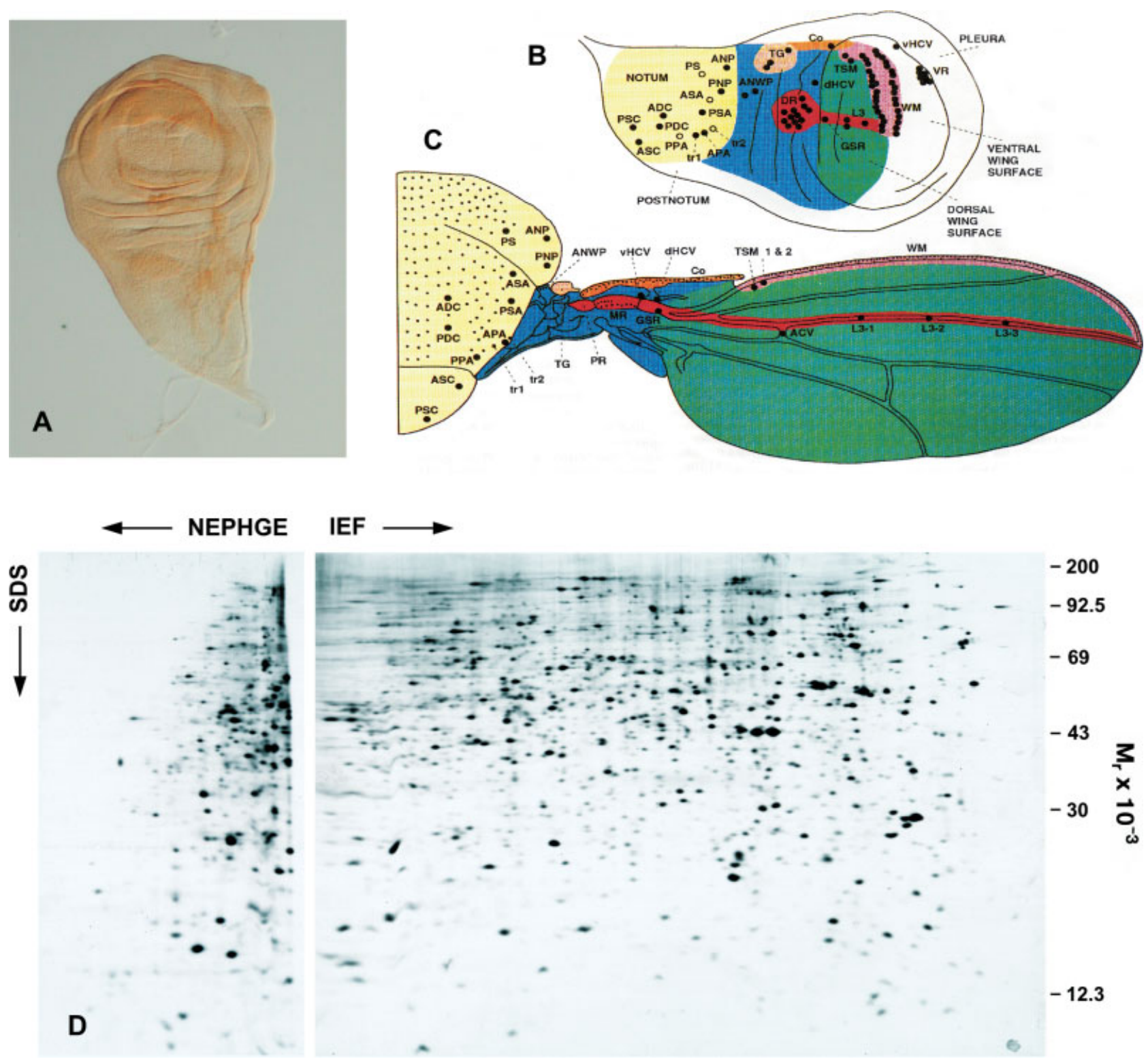

Figure 1. (A) Wing imaginal disc of late third instar larvae of Drosophila melanogaster. Schematic diagrams of an imaginal wing disc from late third instar larvae (B) and of the heminotum and wing that will give rise to metamorphosis (C). The fates of different regions of the disc are indicated by similar colouring of the corresponding adult structures. Noncoloured regions, such as the presumptive ventral wing surface, thoracic pleura and postnotum, correspond to structures not represented in (C), or regions of uncertain fate. Large circles in (C) represent notum macrochaete and the largest sensilla campaniformia in the wing. Small circles denote notum microchaetae and other sensory organs. (D) 2-DE maps (IEF, and NEPHGE) of total $\left[{ }^{35} \mathrm{~S}\right]$ methionine $+\left[{ }^{35} \mathrm{~S}\right]$ cysteine-labeled polypeptides from wing imaginal discs of late third instar larvae. Cells were pulse labeled for $1 \mathrm{~h}$ with $\left[{ }^{35} \mathrm{~S}\right]$ methionine $+\left[{ }^{35} \mathrm{~S}\right]$ cysteine $(1 \mathrm{mCi} / \mathrm{mL})$ and processed as described in Section 2.1. A total of $10^{6} \mathrm{TCA}$-precipitable cpm were applied per gel and 1492 polypeptides were separated and quantified. The $\mathrm{pH}$ ranges were 9.0 (left) to 7.5 (right) in the basic gels and 7.0 (left) to 4.4 (right) in the acidic gels.

\section{Discussion}

This study is part of a major effort in our laboratory to monitor developmental changes in Drosophila polypeptides involved in cell proliferation and differentiation. We have shown previously that the quantitative 2-D wing imaginal disc database can be used to detect differences in the protein patterns associated with specific mutations and stages of development. The limiting factor in such studies is identification of the polypeptides of interest, which is almost impossible using only wing imaginal discs as material. We considered this problem ten years ago but the circumstances then were unfavorable as the Drosophila genome had not yet been sequenced and classic Edman degradation was the only 


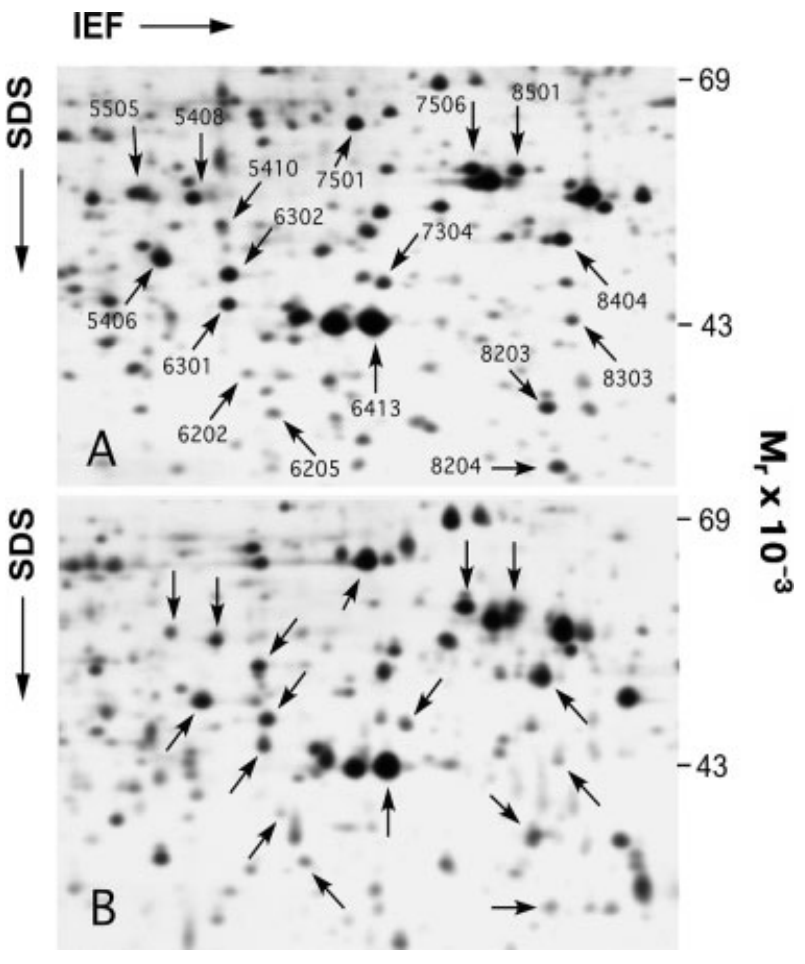

Figure 2. Two-dimensional gel of acidic (IEF) $\left[{ }^{35} \mathrm{~S}\right]$ methionine + $\left[{ }^{35} \mathrm{~S}\right]$ cysteine-labelled polypeptides from wing imaginal disc (A) and Schneider cells (B). Only a small region of the gel is shown. The $\mathrm{pH}$ ranges from 5.6 (left) to 4.6 (right). Arrows indicate some of the polypeptides common to the two samples.

available approach for identifying polypeptides [15]. Peptide mass fingerprinting by MALDI-TOF MS is an excellent technique for identifying proteins in 2-D gels, especially in the case of well-defined genomes such as that of Drosophila.

In the present work we have used the Schneider cell line as our source for purifying some wing disc proteins, taking advantage of the possibility of obtaining large numbers of cultured cells. This cell line is stable and has no tendency to differentiate morphologically during serial passage. It may express a set of differentiated functions characteristic of a cell type normally found during some stage of Drosophila development beyond that of the original cell line, or its gene expression pattern may have no counterpart in normal development. Regardless of its present state, the cell line was found to share more than 600 polypeptides with the wing imaginal disc. The present experimental approach has enabled us to identify 100 spots by PMF, and to identify them from their MS/MS spectra. We determined a total of 417 internal sequences. Tables 1 and 2 list the polypeptides identified in the database and include the corresponding accession numbers in the Drosophila genome database (http//flybase.bio.indiana.edu), which is possibly the most complete currently available database of a eukaryotic organism, in which one can find extensive genetic and molecular information about each polypeptide.
The 100 identified polypeptides represent $6.7 \%$ of the 1492 polypeptides recorded in the database. As the database is quantitative, the 81 polypeptides identified in the acidic gels (IEF) constitute $16.9 \%$ of the 'counts' of the database. Tubulin alpha chain (SSP 7507) is the major polypeptide with $4401 \mathrm{cpm}$ while CG 1354 (SSP 1414) is the rarest, with $82 \mathrm{cpm}$. In the basic gels (NEPHGE), the 19 polypeptides identified constitute $13.7 \%$ of the counts loaded on the gel with cyclophilin (SSP 1004) the major one with $7310 \mathrm{cpm}$ and Tudor (SSP 5201) the most minor, with $471 \mathrm{cpm}$. Tables 1 and 2 also include the abundances of all the identified polypeptides relative to the sum of the radioactivity in all the spots of the gel. We loaded $10^{6} \mathrm{cpm}$ on the IEF gels and recovered $644000 \mathrm{cpm}$ in the total of 1226 acidic spots detected, while on NEPHGE gels we recovered $242000 \mathrm{cpm}$ in the 266 spots detected. Taken together these data indicate that we detected in our database practically $90 \%$ of the radioactivity applied to the gels.

The genes encoded the detected polypeptides mapped over the four Drosophila chromosomes in proportion consistent with the chromosome size: 47 polypeptides on chromosome 2, 37 on chromosome 3, 15 on the $\mathrm{X}$ chromosome and only one on chromosome 4. All cellular organelles were represented in the subcellular location of the identified polypeptides. Our data thus validate the methods of sample preparation and extraction used. Mitochondria are the organelles most highly represented with 11 polypeptides identified.

In most cases analyzed the experimental $\mathrm{p} I$ and $M_{\mathrm{r}}$ values were in good agreement with the theoretical values for the proteins identified. Only four spots showed significant discrepancies in their isoelectric points. Thus the acidic proteins SSP 0024 and SSP 0410 whose theoretical $\mathrm{p} I$ values are 8.69 and 8.22 respectively, appeared at the basic end of the IEF gels, with experimental $\mathrm{p} I$ values near 7.0. Similarly the basic polypeptides SSP 5201 and SSP 7502 with theoretical $\mathrm{p} I$ values of 6.44 and 6.10 respectively, appeared at the acidic end of the basic gels, with experimental $\mathrm{p} I$ values of 7.5. We detected no protein fragments; in each case the identified spots corresponded to a full-length polypeptide. In certain cases the same protein was found in several spots. Such multiple spots could stem from highly similar isoforms, or post-translational modifications. Three instances where two spots contained the same polypeptide were detected in the acidic gels: polypeptides SSP 5406 and SSP 6401 were identified as CG 8983 (Erp60), and polypeptides SSP 8204 and SSP 8209 as annexin IX. Finally, polypeptides SSP 9102 and SSP 9106 were identified as 14-3-3 \& Epsilon. The proteins identified in this study cover a wide spectrum of biological functions. For example, 15 are involved in biosynthetic pathways (two in amino acid, three in nucleic acid, seven in carbohydrate and three in lipid metabolism), and 14 are enzymes involved in aspects of energy generation (10 glycolysis, one pentose phosphate, and three tricarboxylic pathway). We also identified five proteins involved in protein synthesis, and six in signal transduction. For example, SSP 3105 IEF was identified as CG1803, a polypeptide homo- 

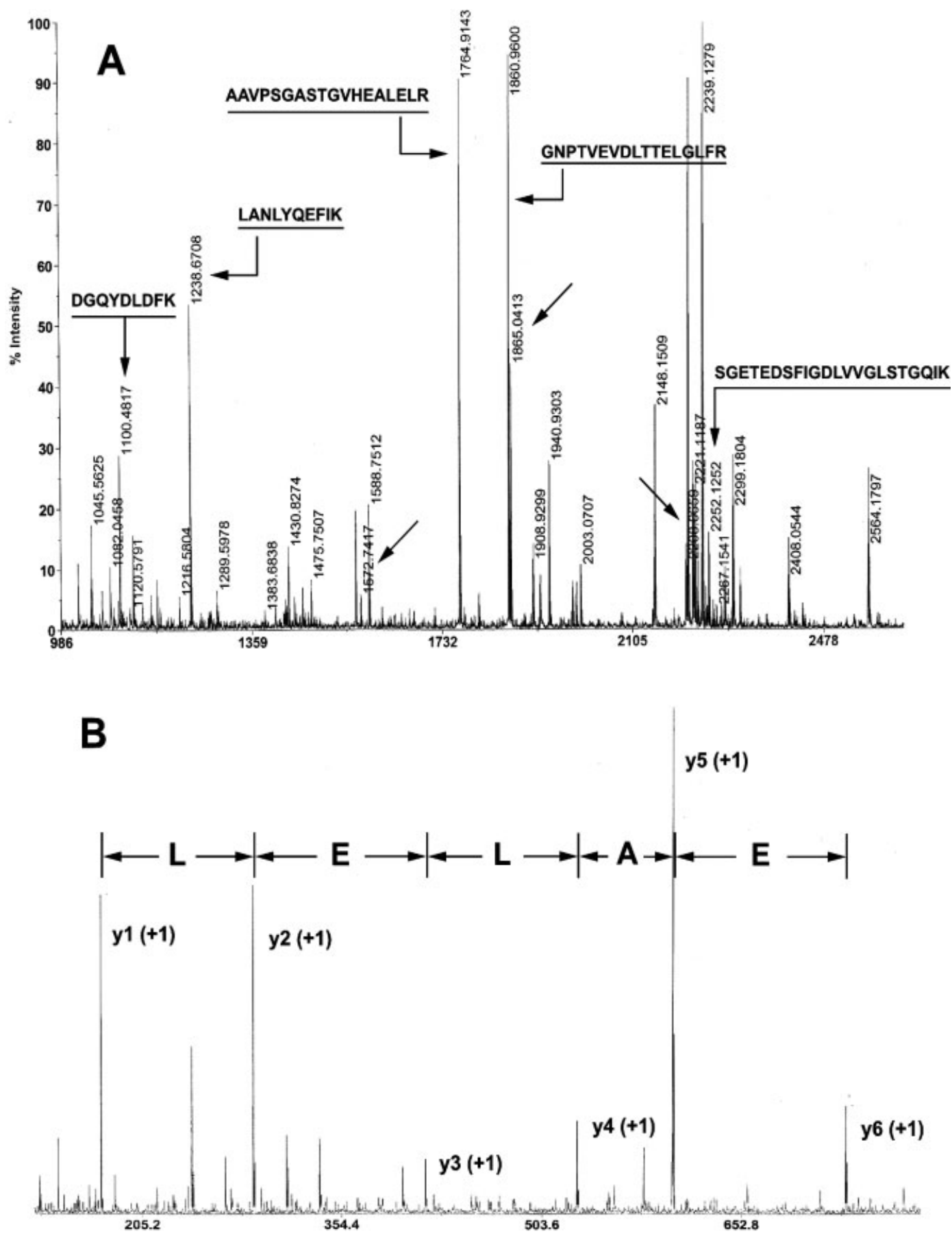

Figure 3. (A) MALDI-TOF MS spectra of the tryptic digest of acidic polypeptide SSP 3303 . The labeled peaks represent 8 of the 17 peptides matched to $D$. melanogaster. The peptides analyzed by MALDI-TOF/TOF MS are also indicated with its sequences underlined. (B) A small detail of the MS/MS spectrum of the 1764.91 Da peptide that was matched to the sequence AAVPSGASTGVHEALELR.

logue of regucalcin that is involved in calcium-mediated signaling and in anterior/posterior axis specification in Drosophila. In addition we identified five cytoskeletal proteins, six in the proteasome and four in the chaperonin T-complex.

\section{Concluding remarks}

The major benefit of this study is to increase the number of identified proteins in the database so that those proteins that change when the database is used for comparative purposes 
in developmental or morphogenetic studies can be identified. For example some time ago we used the wing database to evaluate changes in the pattern of protein synthesis in the wing imaginal discs of Drosophila mutants with abnormal wing disc development [8]. At that time it was impossible to identify any of the polypeptides of interest; these could only be identified by their coordinates. Now we are able to say that one of those spots, SSP 7108 IEF, has been identified as ubiquitin $C$-terminal hydrolase (Uch-L3). That protein appears to be phosphorylated in the tumor suppressor mutants analyzed. It is in this kind of application that the database promises to be most useful.

Using preparative comigration gels of Drosophila wing imaginal discs and Schneider cell proteins, we believe that it should be possible to identify at least 300 proteins on 10-12 preparative gels. This effort is underway, together with characterization of the nuclear and mitochondrial subproteomes. The availability of sequence information for such a large proportion of the proteins observed in 2-D gels should enhance the usefulness of the 2-D gel database, and will be helpful in subsequent studies of Drosophila development and morphogenesis.

We thank Sonsoles Campuzano and Juan Modollel for providing the schemes reproduced in Fig. $1 B$ and $C$. This work was supported by Grant PB87-0449 from Comision Asesora de Investigación Científica Y Técnica and by an institutional grant from Fundación Ramón Areces.

\section{References}

[1] Bate, M., Martinez Arias, A., Development 1991, 112, 755761.

[2] Cohen, S. M., in: Bate, M., Martinez Arias, A. (Eds.), The Development of Drosophila melanogaster, Vol. II, Cold Spring Harbor Laboratory Press. 1993, pp. 747-841.

[3] Campuzano, S., Modolell, J., Trends Genet. 1992, 8, 202-208.

[4] Madhavan, M. M., Schneiderman, H. A., Wilhelm Roux's Arch. Dev. Biol. 1977, 183, 269-305.

[5] Santarén, J. F., García Bellido, A., Dev Genes Evol. 1996, 206, 349-354.

[6] Assiego, R., Santarén, J. F., Electrophoresis 1992, 13, 321 328.

[7] Santarén, J. F., Assiego, R., García Bellido, A., Rouxs Arch. Dev. Biol. 1993, 203, 131-139.

[8] Santarén, J. F., Milán, M., García-Bellido, A., Exp. Cell Res. 1998, 243, 199-206.

[9] O'Farrell, P. H., J. Biol. Chem. 1975, 250, 4007-4021.

[10] O'Farrell, P. Z., Goodman, H. M., O'Farrell, P. H., Cell 1977, 12, 1133-1142.

[11] Santarén, J. F., Electrophoresis 1990, 11, 254-267.

[12] Laskey, R. A., Mills, A. D., Eur. J. Biochem. 1975, 56, 335-341.

[13] Garrels, J. I., J. Biol. Chem. 1979, 254, 7961-7977.

[14] García-Bellido, A., Dev. Biol. 1971, 24, 61-87.

[15] Santarén, J. F., Van Damme, J., Puype, M., Vandekerckhove, J., García-Bellido, A., Exp. Cell Res. 1993, 206, 220-226.

\section{Addendum}

Table 1. Identification by MALDI-TOF and MALDI-TOF/TOF MS of acidic polypeptides (IEF) recorded in the Drosophila wing imaginal disc database

\begin{tabular}{|c|c|c|c|c|c|c|c|}
\hline \multirow{2}{*}{$\begin{array}{l}\text { SSP } \\
\text { no. }\end{array}$} & \multirow[t]{2}{*}{$\mathrm{kDa} / \mathrm{p} /$} & \multirow[t]{2}{*}{$\mathrm{N} / \%^{\mathrm{a})}$} & \multicolumn{2}{|r|}{ MS/MS } & \multirow{2}{*}{$\begin{array}{l}\text { PROTEIN } \\
\text { IDENTIFIED }\end{array}$} & \multirow{2}{*}{$\begin{array}{l}\text { Relative } \\
\text { abun- } \\
\text { dance }\end{array}$} & \multirow{2}{*}{$\begin{array}{l}\text { FLYBASE } \\
\text { Accession } \\
\text { No. }\end{array}$} \\
\hline & & & $\mathrm{MH}^{+}$ & SEQUENCE TAG & & & \\
\hline 0024 & $22.1 / 8.69$ & $9 / 46.9$ & $\begin{array}{l}1332.72 \\
1358.67 \\
2004.08\end{array}$ & $\begin{array}{l}\text { ELALKPOGEGYK } \\
\text { DTNGSOFFITTK } \\
\text { DVVIANSGTLPVSEAFSVAK }\end{array}$ & CG 2852 & 0.43 & 0034753 \\
\hline 0025 & $17.1 / 7.83$ & $5 / 33.3$ & $\begin{array}{l}1390.74 \\
1469.71\end{array}$ & $\begin{array}{l}\text { TFIMVKPDGVOR } \\
\text { NIIHGSDAVESAEK }\end{array}$ & $\begin{array}{l}\text { ABNORMAL WING DISCS } \\
\text { awd }\end{array}$ & 0.39 & 0000150 \\
\hline 0026 & $24.7 / 7.66$ & $7 / 35.6$ & $\begin{array}{l}1214.61 \\
1294.62 \\
1784.92 \\
2066.12\end{array}$ & $\begin{array}{l}\text { NLOYYDISAK } \\
\text { FNVWDTAGQEK } \\
\text { SNYNFEKPFLWLAR } \\
\text { YVATLGVEVHPLIFHTNR }\end{array}$ & $\begin{array}{l}\text { CG } 1404 \text { PROTEIN } \\
\text { (RAN } 10 \text { A) }\end{array}$ & 0.31 & 0020255 \\
\hline 0103 & $27.1 / 7.55$ & $9 / 36.5$ & $\begin{array}{l}1156.60 \\
1160.59 \\
1189.54 \\
1425.77\end{array}$ & $\begin{array}{l}\text { HITIFSPEGR } \\
\text { LYQVEYAFK } \\
\text { TDPAGYFSGFK } \\
\text { NIVPETVTHLFR }\end{array}$ & $\begin{array}{l}\text { PROTEASOME \& ALPHA } \\
6 \text { SUBUNIT }\end{array}$ & 0.21 & 0026781 \\
\hline 0206 & $35.6 / 7.14$ & $13 / 37.7$ & $\begin{array}{l}1329.54 \\
1485.64 \\
1670.87\end{array}$ & $\begin{array}{l}\text { DEDTNYGYPQK } \\
\text { DEDTNYGYPQKR } \\
\text { TVEELRPEVVSPTSK }\end{array}$ & $\begin{array}{l}\text { RECEPTOR OF ACTIVATED } \\
\text { PROTEIN KINASE C1 } \\
\text { (RAC K1) }\end{array}$ & 0.02 & 0020618 \\
\hline
\end{tabular}


Table 1. Continued

\begin{tabular}{|c|c|c|c|c|c|c|c|}
\hline \multirow{2}{*}{$\begin{array}{l}\text { SSP } \\
\text { no. }\end{array}$} & \multirow[t]{2}{*}{$\mathrm{kDa} / \mathrm{p} /$} & \multirow[t]{2}{*}{$\mathrm{N} / \%^{\mathrm{a})}$} & \multicolumn{2}{|r|}{ MS/MS } & \multirow{2}{*}{$\begin{array}{l}\text { PROTEIN } \\
\text { IDENTIFIED }\end{array}$} & \multirow{2}{*}{$\begin{array}{l}\text { Relative } \\
\text { abun- } \\
\text { dance }\end{array}$} & \multirow{2}{*}{$\begin{array}{l}\text { FLYBASE } \\
\text { Accession } \\
\text { No. }\end{array}$} \\
\hline & & & $\mathrm{MH}^{+}$ & SEQUENCE TAG & & & \\
\hline 0410 & $54.5 / 8.22$ & $18 / 32.9$ & $\begin{array}{l}1026.59 \\
1438.84 \\
1472.79 \\
1553.72 \\
1610.86\end{array}$ & $\begin{array}{l}\text { AVDSLVPIGR } \\
\text { GIRPAINVGLSVSR } \\
\text { GKHALIIYDDLSK } \\
\text { EAYPGDVFYLHSR } \\
\text { TGAIVDVPVGDELLGR }\end{array}$ & $\begin{array}{l}\text { BELLWETHER (blw) } \\
\text { ATP SYNTHASE ALPHA CHAIN }\end{array}$ & 0.16 & 0011211 \\
\hline 1309 & $35.5 / 6.60$ & $7 / 28.9$ & $\begin{array}{l}1205.60 \\
1250.65 \\
1526.83 \\
1750.83\end{array}$ & $\begin{array}{l}\text { VIGSGTNLDSSR } \\
\text { QVVDSAYEVIK } \\
\text { QILTPTEVEQLQK } \\
\text { NPOITASTDFAASANSR }\end{array}$ & $\begin{array}{l}\text { ECDYSONE-INDUCIBLE } \\
\text { GENE L3 } \\
\text { Imp L3 }\end{array}$ & 0.03 & 0001258 \\
\hline 1414 & $44.9 / 6.26$ & $9 / 26.2$ & $\begin{array}{l}1216.64 \\
1560.75 \\
1701.78 \\
1813.90 \\
2010.94\end{array}$ & $\begin{array}{l}\text { DLEIISEELR } \\
\text { NYTVEDGDIIFFK } \\
\text { FEDWNAHDIEALNK } \\
\text { GLOLEYFFTAGPDEVK } \\
\text { AFEDPDVTHVEGEVDPVR }\end{array}$ & CG 1354 & 0.01 & 0030151 \\
\hline 1503 & $63.0 / 6.33$ & $22 / 44$ & $\begin{array}{l}1081.61 \\
1464.72 \\
1594.80 \\
1646.84\end{array}$ & $\begin{array}{l}\text { HLYVPTVPR } \\
\text { KIDSDLEGHPTPR } \\
\text { TVAFVSTFATFFTR } \\
\text { SGPPSVLIDMFGISAR }\end{array}$ & CG 8036 & 0.21 & 0037607 \\
\hline 2002 & $17.1 / 6.73$ & $8 / 59.5$ & $\begin{array}{l}973.55 \\
1145.57 \\
1353.65 \\
1612.74\end{array}$ & $\begin{array}{l}\text { YVIFYIR } \\
\text { QIDVETVADR } \\
\text { YIQATDLSEASR } \\
\text { NAEYDOFLEDIQK }\end{array}$ & TWINSTAR (tsr) & 0.40 & 0011726 \\
\hline 2111 & $23.8 / 6.75$ & $7 / 22.5$ & $\begin{array}{l}945.46 \\
1062.61 \\
1850.04\end{array}$ & $\begin{array}{l}\text { APADPEAFKK } \\
\text { AIQVYLVEK } \\
\text { LLNLQAGEHLKPEFLK }\end{array}$ & $\begin{array}{l}\text { GLUTATHIONE } S \\
\text { TRANSFERASE D1 } \\
\text { GstD1 }\end{array}$ & 0.01 & 0001149 \\
\hline 2115 & $20.2 / 6.10$ & $9 / 41.6$ & $\begin{array}{l}793.42 \\
1248.55 \\
1372.77 \\
1545.79\end{array}$ & $\begin{array}{l}\text { IQNYQK } \\
\text { EQLEAEAQGHH } \\
\text { LVPVAGLVDSFQK } \\
\text { IAQSSINWSALAER }\end{array}$ & ATP SYNTHASE, SUBUNIT d & 0.06 & 0016120 \\
\hline 2318 & $35.9 / 6.21$ & $13 / 41.5$ & 1108.59 & REDLFITSK & CG 6048 & 0.02 & 0036182 \\
\hline 2508 & $56.4 / 6.07$ & $9 / 27.9$ & $\begin{array}{l}1157.59 \\
1390.68 \\
1513.77 \\
1732.92\end{array}$ & $\begin{array}{l}\text { SDKGGNPDLVR } \\
\text { GSEKAEEVGIDEK } \\
\text { VEQFVLTSPHDNK } \\
\text { YLIATSEOPIAAYHR }\end{array}$ & CG 17259 & 0.27 & 0031497 \\
\hline 2512 & $55.6 / 6.24$ & $12 / 27.6$ & $\begin{array}{l}1141.56 \\
1179.56 \\
1360.74 \\
1568.80 \\
1774.91\end{array}$ & $\begin{array}{l}\text { AFEAYNEGLK } \\
\text { FQEALEDAEK } \\
\text { YDPTNAILLQGR } \\
\text { AEEEKEQGNLFFK } \\
\text { ALELDPNNAEAIEGYR }\end{array}$ & $\begin{array}{l}\text { HSP 70/HSP } 90 \\
\text { Organizing Protein Homolog }\end{array}$ & 0.39 & 0024352 \\
\hline 2701 & $94.3 / 6.18$ & $18 / 21$ & $\begin{array}{l}760.38 \\
999.56 \\
1092.56 \\
1340.69\end{array}$ & $\begin{array}{l}\text { FYAFGR } \\
\text { GGGQIIPTTR } \\
\text { VNFTVDEIR } \\
\text { DLVFITHPDQR }\end{array}$ & $\begin{array}{l}\text { ELONGATION FACTOR } \mathbf{2 b} \\
\text { (EF-2b) }\end{array}$ & 0.41 & 0000559 \\
\hline 2710 & $105.7 / 6.05$ & 29/33.2 & $\begin{array}{l}1011.53 \\
1092.60 \\
1112.49 \\
1439.68\end{array}$ & $\begin{array}{l}\text { AVIHGDPFR } \\
\text { LEALVGSTFR } \\
\text { DNNYFFHR } \\
\text { DLIHYGNWEHR }\end{array}$ & CG 14476 & 0.25 & 0027588 \\
\hline 3103 & $24.7 / 5.96$ & $8 / 39.1$ & $\begin{array}{l}1139.61 \\
1140.63 \\
1341.71 \\
1520.75\end{array}$ & $\begin{array}{l}\text { IAVHQPEFAK } \\
\text { ALFIISPDHK } \\
\text { VVATPANWTPGTK } \\
\text { LGQTVPNFEADTTK }\end{array}$ & $\begin{array}{l}\text { PEROXIREDOXIN } 2540 \\
\text { Prx2540-2 }\end{array}$ & 0.65 & 0033518 \\
\hline
\end{tabular}


Table 1. Continued

\begin{tabular}{|c|c|c|c|c|c|c|c|}
\hline \multirow{2}{*}{$\begin{array}{l}\text { SSP } \\
\text { no. }\end{array}$} & \multirow[t]{2}{*}{$\mathrm{kDa} / \mathrm{p} /$} & \multirow[t]{2}{*}{$\mathrm{N} / \%^{\mathrm{a})}$} & \multicolumn{2}{|r|}{ MS/MS } & \multirow{2}{*}{$\begin{array}{l}\text { PROTEIN } \\
\text { IDENTIFIED }\end{array}$} & \multirow{2}{*}{$\begin{array}{l}\text { Relative } \\
\text { abun- } \\
\text { dance }\end{array}$} & \multirow{2}{*}{$\begin{array}{l}\text { FLYBASE } \\
\text { Accession } \\
\text { No. }\end{array}$} \\
\hline & & & $\mathrm{MH}^{+}$ & SEQUENCE TAG & & & \\
\hline 3105 & $33.6 / 6.02$ & $16 / 50.2$ & $\begin{array}{l}1175.53 \\
1295.61 \\
1470.79 \\
1556.71 \\
1692.73\end{array}$ & $\begin{array}{l}\text { YIGDEFEFR } \\
\text { FDOPAPAGTTYK } \\
\text { VVIVNWDGVSPSAK } \\
\text { FYYIDTTDYEVK } \\
\text { SYDYDFETGVASNPK }\end{array}$ & $\begin{array}{l}\text { CG } 1803 \\
\text { REGUCALCIN HOMOLOGUE }\end{array}$ & 0.08 & 0030362 \\
\hline 3205 & $31.0 / 6.10$ & $9 / 43$ & $\begin{array}{l}1325.60 \\
1353.69 \\
1664.86 \\
2049.87\end{array}$ & $\begin{array}{l}\text { HSYDTTYPVSR } \\
\text { DPEVLVATEQRP } \\
\text { RPYGVGLLVAGYDER } \\
\text { NDDDDDRPSPPEEPAAGPR }\end{array}$ & $\begin{array}{l}\text { PROTEASOME } 35 \mathrm{kDa} \\
\text { SUBUNIT } \\
\text { Pros } 35\end{array}$ & 0.09 & 0003151 \\
\hline 3303 & $46.5 / 6.10$ & $17 / 52.7$ & $\begin{array}{l}1100.48 \\
1238.67 \\
1764.91 \\
1860.96 \\
2252.13\end{array}$ & $\begin{array}{l}\text { DGQYDLDFK } \\
\text { LANLYKEFIK } \\
\text { AAVPSGASTGVHEALELR } \\
\text { GNPTVEVDLTTELGLFR } \\
\text { SGETEDSFIGDLVVGLSTGQIK }\end{array}$ & ENOLASE (Eno) & 0.12 & 0000579 \\
\hline 3403 & $59.3 / 5.97$ & 13/33.8 & $\begin{array}{l}1477.76 \\
1521.81 \\
1565.79 \\
1807.91\end{array}$ & $\begin{array}{l}\text { VVDAEWQILYNK } \\
\text { OVKPFVEEGVHPR } \\
\text { LPIGDVATOYFADR } \\
\text { VTGGSLEESOLVSGVAFK }\end{array}$ & CG 8351 & 0.37 & 0037632 \\
\hline 3405 & $53.2 / 5.93$ & $11 / 29$ & $\begin{array}{l}1752.94 \\
2063.08 \\
2443.17 \\
2585.36\end{array}$ & $\begin{array}{l}\text { GLVDDLNLPNAGVTVOK } \\
\text { VEYINGLGSFVDSHTLLAK } \\
\text { YPDIPGAVEYGITSDDLFSLDR } \\
\text { SGLTINTLINTVGIHPTTAEEFTR }\end{array}$ & $\begin{array}{l}\text { THIOREDOXIN REDUCTASE-1 } \\
\text { Trxr-1 }\end{array}$ & 0.11 & 0020653 \\
\hline 4001 & $26.6 / 6.0$ & $11 / 51$ & $\begin{array}{l}1279.65 \\
1363.70 \\
1567.77 \\
1683.83\end{array}$ & $\begin{array}{l}\text { IQYGGSVTAANAK } \\
\text { AIFGESDALIAEK } \\
\text { DIGADWVILGHSER } \\
\text { TATPDQAQEVHAFLR }\end{array}$ & $\begin{array}{l}\text { TRIOSE PHOSPHATE } \\
\text { ISOMERASE (Tpi) }\end{array}$ & 0.08 & 0003738 \\
\hline 4108 & $26.0 / 5.92$ & $11 / 49.6$ & $\begin{array}{l}1231.64 \\
1311.62 \\
1523.85 \\
1597.77 \\
1660.83\end{array}$ & $\begin{array}{l}\text { NVLPAAVEQYK } \\
\text { NQSEYETVLTK } \\
\text { LDLISQQLVPEIR } \\
\text { VREDHVSSVLDDAR } \\
\text { AQINONVELFIDEK }\end{array}$ & $\begin{array}{l}\text { VACUOLAR H+ ATPase } \\
26 \text { kDa E SUBUNIT }\end{array}$ & 0.06 & 0015324 \\
\hline 4111 & $25.1 / 5.88$ & $7 / 27.4$ & $\begin{array}{l}1170.61 \\
1265.66 \\
2124.01 \\
2280.12\end{array}$ & $\begin{array}{l}\text { GEHLTPEFLK } \\
\text { LHLDSGHLFAR } \\
\text { LAELPYYQEVNGDGADELK } \\
\text { RLAELPYYOEVNGDGADELK }\end{array}$ & CG 16936 & 0.07 & 0027590 \\
\hline 4201 & $35.7 / 5.77$ & $9 / 26.2$ & $\begin{array}{l}930.48 \\
1120.63 \\
1177.61 \\
1521.77 \\
1884.89\end{array}$ & $\begin{array}{l}\text { HAIDVGYR } \\
\text { REDIFLVTK } \\
\text { YVDDNTLLPK } \\
\text { SIGVSNFNSEOLAR } \\
\text { HIDTAYFYONEAEVGK }\end{array}$ & CG 10638 & 0.09 & 0036290 \\
\hline 4207 & $36.8 / 5.66$ & $12 / 32$ & $\begin{array}{l}1343.67 \\
1566.82 \\
1927.11 \\
2116.17\end{array}$ & $\begin{array}{l}\text { HIDTAPVYGNEK } \\
\text { SENITVTAYSPLGSK } \\
\text { VPPVSNRPHEVEPTIKK } \\
\text { IRPANNQIEHHVYLQQR }\end{array}$ & CG 2767 (LD 24679 p) & 0.09 & 0037537 \\
\hline 4301 & $48.9 / 5.93$ & $19 / 48$ & $\begin{array}{l}1034.56 \\
1466.88 \\
1523.68 \\
1693.85 \\
1718.82 \\
2599.36\end{array}$ & $\begin{array}{l}\text { RVEEFNLK } \\
\text { LVTGWOKPIVIGR } \\
\text { EYEAAGIWYEHR } \\
\text { ETSTNPIASIFAWTR } \\
\text { DYOETFEFINTLAK } \\
\text { SOLILPFLDIELHTYDLGIENR }\end{array}$ & $\begin{array}{l}\text { ISOCITRATE } \\
\text { DEHYDROGENASE } \\
\text { Idh }\end{array}$ & 0.05 & 0001248 \\
\hline
\end{tabular}


Table 1. Continued

\begin{tabular}{|c|c|c|c|c|c|c|c|}
\hline \multirow{2}{*}{$\begin{array}{l}\text { SSP } \\
\text { no. }\end{array}$} & \multirow[t]{2}{*}{$\mathrm{kDa} / \mathrm{p} /$} & \multirow[t]{2}{*}{$\mathrm{N} / \%^{\mathrm{a})}$} & \multicolumn{2}{|r|}{ MS/MS } & \multirow{2}{*}{$\begin{array}{l}\text { PROTEIN } \\
\text { IDENTIFIED }\end{array}$} & \multirow{2}{*}{$\begin{array}{l}\text { Relative } \\
\text { abun- } \\
\text { dance }\end{array}$} & \multirow{2}{*}{$\begin{array}{l}\text { FLYBASE } \\
\text { Accession } \\
\text { No. }\end{array}$} \\
\hline & & & $\mathrm{MH}^{+}$ & SEQUENCE TAG & & & \\
\hline 4306 & $48.5 / 5.75$ & $16 / 37$ & $\begin{array}{l}1205.70 \\
1536.84 \\
1761.88 \\
1869.92\end{array}$ & $\begin{array}{l}\text { YQIHIPLPPK } \\
\text { OILONEQPLOVAR } \\
\text { TMLELINOLDGFDPR } \\
\text { ESDTGLAPPALWDLAADK }\end{array}$ & Rpt1 & 0.15 & 0028687 \\
\hline 4401 & $59.3 / 5.97$ & $12 / 24.4$ & $\begin{array}{l}1365.61 \\
1521.80 \\
1565.79 \\
1807.94\end{array}$ & $\begin{array}{l}\text { GGAEQFLEETER } \\
\text { OVKPFVEEGVHPR } \\
\text { LPIGDVATQYFADR } \\
\text { VTGGSLEESOLVSGVAFK }\end{array}$ & CG 8351 & 0.06 & 0037632 \\
\hline 4404 & $47.3 / 5.82$ & $9 / 24.5$ & $\begin{array}{l}1021.62 \\
1216.63 \\
1495.79 \\
2165.06\end{array}$ & $\begin{array}{l}\text { HIILLAEGR } \\
\text { VADISLAEWGR } \\
\text { ILDEEVASLHLEK } \\
\text { QATYLGVSOTGPFKPDHYR }\end{array}$ & $\begin{array}{l}\text { ADENOSYLHOMO-CYSTEINASE } \\
\text { Ahcy } 13\end{array}$ & 0.01 & 0014455 \\
\hline 4702 & $107.7 / 5.77$ & $23 / 26.5$ & $\begin{array}{l}1017.50 \\
1422.67 \\
1640.78 \\
1672.84 \\
2060.99\end{array}$ & $\begin{array}{l}\text { LKATIDNDK } \\
\text { SVFDEVYPDPVR } \\
\text { FENQFVNEITSGQK } \\
\text { TITIALADGGTPDNTGR } \\
\text { TNFYAESGGQIYDQGALVK }\end{array}$ & ALANYL-tRNA SYNTHASE & 0.21 & 0027094 \\
\hline 5211 & $30.6 / 5.61$ & $13 / 34.2$ & $\begin{array}{l}1134.55 \\
1184.67 \\
1438.66 \\
1696.95 \\
1743.96\end{array}$ & $\begin{array}{l}\text { RGHGAFYNGR } \\
\text { VLTQFNPLPR } \\
\text { FIGEEESSGAEGVK } \\
\text { RVLAAATPELAQEISK } \\
\text { VTELGLVYNPILEQR }\end{array}$ & CG 9391 & 0.01 & 0037063 \\
\hline 5305 & $40.2 / 5.46$ & $9 / 27$ & 2050.02 & FVAEGEPHIDGEPGDLIVR & CG 4164 & 0.18 & 0031256 \\
\hline 5406 & $55.2 / 5.62$ & $17 / 38.1$ & $\begin{array}{l}1114.57 \\
1248.61 \\
1375.67 \\
1407.60 \\
1532.70 \\
1582.68\end{array}$ & $\begin{array}{l}\text { YSVSGYPTLK } \\
\text { NFDDLVINNGK } \\
\text { FGHSSEKEVLDK } \\
\text { QDEVSQDYNGPR } \\
\text { FEGSSESDLSTFVK } \\
\text { DTTLFGYFSDSDSK }\end{array}$ & Erp60 & 0.55 & 0033663 \\
\hline 5408 & $58.0 / 5.60$ & $16 / 36.4$ & $\begin{array}{l}1090.58 \\
1316.63 \\
1840.90\end{array}$ & $\begin{array}{l}\text { EAIAIEAFAR } \\
\text { GATQQILDEADR } \\
\text { QLIYNYPEQLFADAR }\end{array}$ & CG 7033 & 0.32 & 0030086 \\
\hline 5410 & $46.7 / 5.48$ & $17 / 42.5$ & $\begin{array}{l}764.43 \\
1168.49 \\
1279.61 \\
1411.75 \\
1879.91\end{array}$ & $\begin{array}{l}\text { FLDTLR } \\
\text { ASDAQEYDGGR } \\
\text { TASDIVSWASDK } \\
\text { KPAIVSVDPWDGK } \\
\text { VGSVNADADSTLSGQFGVR }\end{array}$ & CaBP1 & 0.17 & 0025678 \\
\hline 5501 & $76.2 / 5.62$ & $12 / 22$ & $\begin{array}{l}1309.67 \\
1598.88 \\
1650.86 \\
1820.98\end{array}$ & $\begin{array}{l}\text { LLEQPDVQPDR } \\
\text { TALTHYLEITAIPR } \\
\text { LHSIQNQRPPFDAK } \\
\text { LHPTDVHVTAVLVEYK }\end{array}$ & $\begin{array}{l}\text { CYTOCHROME P450 } \\
\text { REDUCTASE (Cpr) }\end{array}$ & 0.28 & 0015623 \\
\hline 6001 & $21.7 / 5.52$ & $6 / 33$ & $\begin{array}{l}920.50 \\
1211.67 \\
1212.64 \\
1610.76\end{array}$ & $\begin{array}{l}\text { GLFIIDDK } \\
\text { OITVNDLPGGR } \\
\text { LVQAFQYTDK } \\
\text { DYGVLDEETGIPFR }\end{array}$ & $\begin{array}{l}\text { THIOREDOXIN PEROXIDASE } \\
\text { (Jafrac1) }\end{array}$ & 0.16 & 0040309 \\
\hline 6103 & $30.3 / 5.55$ & $11 / 44.6$ & $\begin{array}{l}1349.68 \\
1452.86 \\
1485.73 \\
1617.87 \\
1800.00\end{array}$ & $\begin{array}{l}\text { SFGEAGDGLVELR } \\
\text { ILYRPIPDQLPK } \\
\text { IYTILGQDYDER } \\
\text { AVVAOFDAGELITQR } \\
\text { LASIISAEGDAEAAGLLAK }\end{array}$ & LETHAL (2) 37 Cc & 0.08 & 0002031 \\
\hline
\end{tabular}


Table 1. Continued

\begin{tabular}{|c|c|c|c|c|c|c|c|}
\hline \multirow{2}{*}{$\begin{array}{l}\text { SSP } \\
\text { no. }\end{array}$} & \multirow[t]{2}{*}{$\mathrm{kDa} / \mathrm{p} /$} & \multirow[t]{2}{*}{$\mathrm{N} / \%^{\mathrm{a})}$} & \multicolumn{2}{|r|}{ MS/MS } & \multirow{2}{*}{$\begin{array}{l}\text { PROTEIN } \\
\text { IDENTIFIED }\end{array}$} & \multirow{2}{*}{$\begin{array}{l}\text { Relative } \\
\text { abun- } \\
\text { dance }\end{array}$} & \multirow{2}{*}{$\begin{array}{l}\text { FLYBASE } \\
\text { Accession } \\
\text { No. }\end{array}$} \\
\hline & & & $\mathrm{MH}^{+}$ & SEQUENCE TAG & & & \\
\hline 6104 & 29.6/5.49 & $8 / 29$ & $\begin{array}{l}908.53 \\
1332.75 \\
1712.73 \\
1736.81\end{array}$ & $\begin{array}{l}\text { FINFVLR } \\
\text { YLSELDVPIKR } \\
\text { TEPGGNDYEIYSDPR } \\
\text { SVVTPEFEEFFYSR }\end{array}$ & CG 10688 & 0.13 & 0036300 \\
\hline 6203 & $44.0 / 5.46$ & $9 / 28$ & $\begin{array}{l}1238.63 \\
1332.67 \\
1360.72 \\
1537.74\end{array}$ & $\begin{array}{l}\text { GENIVLAYCEK } \\
\text { TGGAPQWEQLR } \\
\text { LFNNLDTASPLR } \\
\text { LPAYVOFYEDHR }\end{array}$ & CG 8309 & 0.07 & 0033902 \\
\hline 6205 & $32.6 / 5.43$ & $11 / 49$ & $\begin{array}{l}1205.59 \\
1320.70 \\
1544.78 \\
1575.77 \\
1847.90\end{array}$ & $\begin{array}{l}\text { NSPSYSLYFK } \\
\text { TIYNMVVEVPR } \\
\text { NADFANTIIAETHK } \\
\text { GDNDPIDVIEIGYR } \\
\text { IPDGKPENOFAFNGDAK }\end{array}$ & $\begin{array}{l}\text { NUCLEOSOME REMODELING } \\
\text { FACTOR - } 38 \text { kDa } \\
\text { (NURF - 38) }\end{array}$ & 0.11 & 0016687 \\
\hline 6207 & $41.7 / 5.40$ & $12 / 32$ & $\begin{array}{l}1125.58 \\
1203.62 \\
1216.70 \\
1607.82 \\
1875.98\end{array}$ & $\begin{array}{l}\text { AAFAPHPTTGR } \\
\text { DFGYVLQHPK } \\
\text { LPVVYGIGDKR } \\
\text { ELANIDDLSYTVVR } \\
\text { NLATYLLDNELAQEIR }\end{array}$ & CG 5854 & 0.16 & 0039130 \\
\hline 6301 & $49.9 / 5.51$ & $16 / 39.3$ & $\begin{array}{l}1017.50 \\
1314.69 \\
1590.80 \\
1648.78 \\
1898.93 \\
2060.00\end{array}$ & $\begin{array}{l}\text { YGLEPPGER } \\
\text { NFLIYVQDFR } \\
\text { NTQDFTGHALALFR } \\
\text { DDEYLNEPAVNTIR } \\
\text { NFLIYVQDFREDDPK } \\
\text { YYGGESASITPLEELFQR }\end{array}$ & $\begin{array}{l}\text { GDP DISSOCIATION } \\
\text { INHIBITOR (Gdi) }\end{array}$ & 0.25 & 0004868 \\
\hline 6302 & $48.6 / 5.43$ & $11 / 27.8$ & $\begin{array}{l}1103.65 \\
1243.74 \\
1310.64 \\
1663.93\end{array}$ & $\begin{array}{l}\text { ILVATNLFGR } \\
\text { DFLLKPEILR } \\
\text { GTYVSIHSSGFR } \\
\text { LTLHGLOOHYVNLK }\end{array}$ & HELICASE AT 25E & 0.41 & 0014189 \\
\hline 6303 & $45.8 / 5.43$ & $14 / 43.7$ & $\begin{array}{l}1114.69 \\
1324.68 \\
1387.72 \\
1491.74 \\
1813.91\end{array}$ & $\begin{array}{l}\text { VLITTDLLAR } \\
\text { GFKDQIQDVFK } \\
\text { GRDVIAQAQSGTGK } \\
\text { GVAINFITDDDRR } \\
\text { GIYGYGFEKPSAIQQR }\end{array}$ & $\begin{array}{l}\text { EUKARYOTIC INITIATION } \\
\text { FACTOR 4A (eIF-4A) }\end{array}$ & 0.11 & 0001942 \\
\hline 6304 & $51.8 / 5.67$ & $14 / 34$ & $\begin{array}{l}1134.62 \\
1290.72 \\
1467.70 \\
2150.03 \\
2460.19\end{array}$ & $\begin{array}{l}\text { IPLHELEQR } \\
\text { RIPLHELEQR } \\
\text { ADLTDYIOTHYK } \\
\text { VASEDSGASTATVGLWIDAGSR } \\
\text { SOTDLELEVENLGAHLNAYTSR }\end{array}$ & CG 3731 & 0.20 & 0038271 \\
\hline 6401 & $55.2 / 5.62$ & $14 / 33.8$ & $\begin{array}{l}1582.69 \\
1675.78 \\
2174.08\end{array}$ & $\begin{array}{l}\text { DTTLFGYFSDSDSK } \\
\text { MDATANDVPPEFNVR } \\
\text { YALKDEFSVENLODFVEK }\end{array}$ & CG 8983 (Erp60) & 0.04 & 0033663 \\
\hline 6413 & $41.5 / 5.30$ & $9 / 23$ & $\begin{array}{l}976.45 \\
1132.53 \\
1515.75 \\
1790.90 \\
1954.09\end{array}$ & $\begin{array}{l}\text { AGFAGDDAPR } \\
\text { GYSFTTTAER } \\
\text { IWHHTFYNELR } \\
\text { SYELPDGQVITIGNER } \\
\text { VAPEEHPVLLTEAPLNPK }\end{array}$ & ACTIN 5C & 0.29 & 0000042 \\
\hline 6502 & $68.4 / 5.32$ & $14 / 31.2$ & $\begin{array}{l}1567.77 \\
1723.87 \\
1968.92 \\
2000.01 \\
2496.24\end{array}$ & $\begin{array}{l}\text { LDEILEFANSNFR } \\
\text { RLDEILEFANSNFR } \\
\text { DFQSALYDYFIDTDKK } \\
\text { YLEDLFGGPTVFEPFLR } \\
\text { IDYETSSSASGLOWLNPTOTLGK }\end{array}$ & CG 10602 & 0.19 & 0032721 \\
\hline
\end{tabular}


Table 1. Continued

\begin{tabular}{|c|c|c|c|c|c|c|c|}
\hline \multirow{2}{*}{$\begin{array}{l}\text { SSP } \\
\text { no. }\end{array}$} & \multirow[t]{2}{*}{$\mathrm{kDa} / \mathrm{p} /$} & \multirow[t]{2}{*}{$\mathrm{N} / \%^{\mathrm{a})}$} & \multicolumn{2}{|r|}{ MS/MS } & \multirow{2}{*}{$\begin{array}{l}\text { PROTEIN } \\
\text { IDENTIFIED }\end{array}$} & \multirow{2}{*}{$\begin{array}{l}\text { Relative } \\
\text { abun- } \\
\text { dance }\end{array}$} & \multirow{2}{*}{$\begin{array}{l}\text { FLYBASE } \\
\text { Accession } \\
\text { No. }\end{array}$} \\
\hline & & & $\mathrm{MH}^{+}$ & SEQUENCE TAG & & & \\
\hline 6615 & $71.1 / 5.36$ & $17 / 35$ & $\begin{array}{l}1487.69 \\
1691.71 \\
2774.32\end{array}$ & $\begin{array}{l}\text { TTPSYVAFTDTER } \\
\text { STAGDTHLGGEDFDNR } \\
\text { QTOTFTTYSDNOPGVLIQVYEGER }\end{array}$ & HEAT SHOCK PROTEIN 70-4 & 0.02 & 0001219 \\
\hline 6709 & $88.5 / 5.31$ & $19 / 28.4$ & $\begin{array}{l}1243.65 \\
1495.73 \\
1537.90 \\
1640.74 \\
1860.94 \\
2588.33\end{array}$ & $\begin{array}{l}\text { TADSPVQISAVR } \\
\text { SGGIETLANDYSLR } \\
\text { ALLDAAQIAGLNVLR } \\
\text { SDYEQGPAAFDELK } \\
\text { NDPHVOHELTSIPAR } \\
\text { LIEOVFNKPASTTLNODEAVSR }\end{array}$ & $\begin{array}{l}\text { HSC } 70 \text { CB PROTEIN } \\
\text { (LD } 32979 \mathrm{P} \text { ) } \\
\mathrm{Hsc} 70 \mathrm{Cb}\end{array}$ & 0.17 & 0026418 \\
\hline 7006 & $17.5 / 4.98$ & $6 / 40.9$ & $\begin{array}{l}1226.64 \\
1359.70 \\
1711.88 \\
2682.32\end{array}$ & $\begin{array}{l}\text { VPEGELGEQLR } \\
\text { VHMVGIDIFSNK } \\
\text { EDLKVPEGELGEQLR } \\
\text { EDLQLIAISDDSFLTLMTESGDLR }\end{array}$ & $\begin{array}{l}\text { EUKARYOTIC TRANSLATION } \\
\text { INITIATION FACTOR 5A } \\
\text { (eIF 5A) }\end{array}$ & 0.41 & 0034967 \\
\hline 7102 & $27.6 / 5.46$ & $11 / 57.3$ & $\begin{array}{l}1201.65 \\
1566.78 \\
1707.92 \\
2074.06\end{array}$ & $\begin{array}{l}\text { QQFEQAIPLK } \\
\text { TDELVESAGEIIYK } \\
\text { VTGGLHLINPSELTEK } \\
\text { NIGMAVAGLVADGNFVADIAR }\end{array}$ & $\begin{array}{l}\text { PROTEASOME SUBUNIT } \\
\text { ALPHA TYPE } 3.7\end{array}$ & 0.15 & 0023175 \\
\hline 7105 & $23.2 / 5.28$ & $7 / 36.1$ & $\begin{array}{l}825.47 \\
1455.74 \\
1748.93 \\
1777.98\end{array}$ & $\begin{array}{l}\text { VFHIGPR } \\
\text { FGIQAOTISTDFK } \\
\text { FGPYFIEPVVAGLDPK } \\
\text { MFLGLTGLQTDILTVR }\end{array}$ & $\begin{array}{l}\text { PROTEASOME SUBUNIT BETA } \\
\text { TYPE } 3\end{array}$ & 0.30 & 0026380 \\
\hline 7108 & $37.6 / 5.12$ & $18 / 60$ & $\begin{array}{l}1186.60 \\
1450.81 \\
1540.89 \\
1825.98 \\
1968.92\end{array}$ & $\begin{array}{l}\text { TYIEYEIQK } \\
\text { VVLDRENIFFAK } \\
\text { NLEPIHGLIFLFK } \\
\text { SEQNWIDVVRPIIEK } \\
\text { KDDDVYHFVGYMPIGGR }\end{array}$ & UCH-L3 & 0.14 & 0011327 \\
\hline 7207 & $36.1 / 5.17$ & $8 / 34$ & $\begin{array}{l}1244.55 \\
1600.77 \\
1693.84 \\
1705.82 \\
1824.80\end{array}$ & $\begin{array}{l}\text { SYASGGEDGFVR } \\
\text { FFHLIYEEEFAR } \\
\text { GHFGPINSLAFHPDGK } \\
\text { DQKPNVWYSLNGER } \\
\text { TSNFSFSGNQAAYSTDK }\end{array}$ & $\begin{array}{l}\text { EUKARYOTIC TRANSLATION } \\
\text { INITIATION FACTOR } 3 \\
\text { SUBUNIT } 2 \text { (eIF-3 BETA) } \\
\text { (Trip1) }\end{array}$ & 0.10 & 0015834 \\
\hline 7304 & $47.8 / 5.20$ & $18 / 46$ & $\begin{array}{l}1124.66 \\
1466.73 \\
1662.89 \\
1868.92 \\
2096.06\end{array}$ & $\begin{array}{l}\text { VDILDPALLR } \\
\text { KIEFPHPNEEAR } \\
\text { GAYFLPVIGLVDAEK } \\
\text { DSYLILETLPAEYDAR } \\
\text { TMLELLNOLDGFSSTADIK }\end{array}$ & $\begin{array}{l}\text { RPT5 } \\
\text { Tat-binding protein-1 }\end{array}$ & 0.22 & 0028684 \\
\hline 7402 & $54.5 / 5.25$ & $16 / 43$ & $\begin{array}{l}1341.61 \\
1520.79 \\
1582.89 \\
1896.88\end{array}$ & $\begin{array}{l}\text { NFISQGNYENR } \\
\text { AVVOVFEGTSGIDAK } \\
\text { OIYPPVNVLPSLSR } \\
\text { GFPGYMYTDLATIYER }\end{array}$ & $\begin{array}{l}\text { VACUOLAR ATP SYNTHASE } \\
\text { SUBUNIT B (Vha 55) }\end{array}$ & 0.31 & 0005671 \\
\hline 7404 & $59.4 / 5.19$ & $20 / 37.5$ & $\begin{array}{l}1013.52 \\
1135.60 \\
1257.59 \\
1263.69 \\
1496.73 \\
1655.76\end{array}$ & $\begin{array}{l}\text { LFDLYQSK } \\
\text { FANALEVFPK } \\
\text { FVEGDVTYAEK } \\
\text { KFANALEVFPK } \\
\text { LGITTAEISDGYEK } \\
\text { QYGQEDFLNDLVSK }\end{array}$ & CG 8258 & 0.25 & 0033342 \\
\hline 7412 & $46.6 / 5.16$ & $14 / 36$ & $\begin{array}{l}1237.63 \\
1584.82\end{array}$ & $\begin{array}{l}\text { VVDLTEDTFAK } \\
\text { ELSAPAEADLGEVKR }\end{array}$ & CG1837 & 0.02 & 0030329 \\
\hline 7507 & $49.8 / 5.00$ & $11 / 30.4$ & $\begin{array}{l}1071.60 \\
1410.77 \\
1718.88 \\
1785.00\end{array}$ & $\begin{array}{l}\text { EIVDLVDR } \\
\text { QLFHPEQLITGK } \\
\text { NLDIERPTYTNLNR } \\
\text { IHFPLVTYAPVISAEK }\end{array}$ & TUBULIN ALPHA CHAIN & 0.68 & 0003884 \\
\hline
\end{tabular}


Table 1. Continued

\begin{tabular}{|c|c|c|c|c|c|c|c|}
\hline \multirow{2}{*}{$\begin{array}{l}\text { SSP } \\
\text { no. }\end{array}$} & \multirow[t]{2}{*}{$\mathrm{kDa} / \mathrm{p} /$} & \multirow[t]{2}{*}{$\mathrm{N} / \%^{\mathrm{a})}$} & \multicolumn{2}{|r|}{ MS/MS } & \multirow{2}{*}{$\begin{array}{l}\text { PROTEIN } \\
\text { IDENTIFIED }\end{array}$} & \multirow{2}{*}{$\begin{array}{l}\text { Relative } \\
\text { abun- } \\
\text { dance }\end{array}$} & \multirow{2}{*}{$\begin{array}{l}\text { FLYBASE } \\
\text { Accession } \\
\text { No. }\end{array}$} \\
\hline & & & $\mathrm{MH}^{+}$ & SEQUENCE TAG & & & \\
\hline & & & $\begin{array}{l}1824.99 \\
1993.89\end{array}$ & $\begin{array}{l}\text { VGINYQPPTVVPGGDLAK } \\
\text { TVGGGDDSFNTFFSETGAGK }\end{array}$ & & & \\
\hline 7603 & $68.2 / 5.19$ & $24 / 46.9$ & 1403.72 & VASWEFNPLNVK & $\begin{array}{l}\text { VACUOLAR ATP SYNTHASE } \\
\text { CATALITIC SUBUNIT A } \\
\text { ISOFORM } 2 \text { (Vha 68-2) }\end{array}$ & 0.18 & 0020367 \\
\hline 7702 & $88.8 / 5.24$ & $23 / 39.3$ & $\begin{array}{l}1256.64 \\
1542.83 \\
1823.91\end{array}$ & $\begin{array}{l}\text { EIDIGIPDATGR } \\
\text { LDQLIYIPLPDDK } \\
\text { ELQELVQYPVEHPDK }\end{array}$ & $\begin{array}{l}\text { TER } 94 \\
\text { TRANSITIONAL ENDOPLASMIC } \\
\text { RETICULUM ATPase }\end{array}$ & 0.32 & 0024923 \\
\hline 8106 & $28.2 / 4.90$ & $11 / 41$ & $\begin{array}{l}1165.58 \\
1549.74 \\
2157.99\end{array}$ & $\begin{array}{l}\text { YLAEVATGDAR } \\
\text { SVTETGVELSNEER } \\
\text { QAFDDIAELDTLNEDSYK }\end{array}$ & 14-3-3 \& ZETA & 0.44 & 0004907 \\
\hline 8112 & $15.1 / 4.97$ & $4 / 36$ & $\begin{array}{l}773.39 \\
1031.54 \\
1776.73 \\
1952.87\end{array}$ & $\begin{array}{l}\text { FFFGGAK } \\
\text { IGELVESER } \\
\text { DATENFEDVGHSNDAR } \\
\text { SEPTWSTEQOTEESSVK }\end{array}$ & CYTOCHROME b5 & 0.03 & 0033189 \\
\hline 8204 & $35.9 / 4.99$ & $13 / 34$ & $\begin{array}{l}929.44 \\
1418.68 \\
1911.93\end{array}$ & $\begin{array}{l}\text { IDYFSER } \\
\text { TIAQFYEQSFGK } \\
\text { QIFLEYENLSGNDIEK }\end{array}$ & ANNEXIN IX & 0.25 & 0000083 \\
\hline 8209 & $35.9 / 4.99$ & $11 / 29.9$ & $\begin{array}{l}929.43 \\
1418.69 \\
1911.93\end{array}$ & $\begin{array}{l}\text { IDYFSER } \\
\text { TIAQFYEQSFGK } \\
\text { QIFLEYENLSGNDIEK }\end{array}$ & ANNEXIN IX & 0.04 & 0000083 \\
\hline 8404 & $54.1 / 4.93$ & $16 / 37$ & $\begin{array}{l}1367.74 \\
1406.68 \\
1439.78 \\
1677.92\end{array}$ & $\begin{array}{l}\text { IINVIGEPIDER } \\
\text { AHGGYSVFAGVGER } \\
\text { VALTGLTVAEYFR } \\
\text { LVLEVAOHLGENTVR }\end{array}$ & ATP SYNTHASE BETA CHAIN & 0.30 & 0010217 \\
\hline 8504 & $50.1 / 4.76$ & $15 / 47.2$ & $\begin{array}{l}1053.60 \\
1130.58 \\
1620.81 \\
1958.97\end{array}$ & $\begin{array}{l}\text { YLTVAAIFR } \\
\text { FPGQLNADLR } \\
\text { LHFFMPGFAPLTSR } \\
\text { GHYTEGAELVDSVLDVVR }\end{array}$ & $\begin{array}{l}\text { TUBULIN BETA-1 CHAIN } \\
\text { at 56D }\end{array}$ & 0.26 & 0003887 \\
\hline 8709 & $90.2 / 4.93$ & $25 / 36.5$ & $\begin{array}{l}1141.56 \\
1284.67 \\
1434.71 \\
1580.70 \\
2236.07\end{array}$ & $\begin{array}{l}\text { FTFQTEVNR } \\
\text { YSQFINFPIR } \\
\text { QEHIYYIAGANR } \\
\text { EEAODFLEEDTVR } \\
\text { DSSEPLTQTHFIAEGEVTFK }\end{array}$ & GLYCOPROTEIN 93 & 0.25 & 0039562 \\
\hline 9002 & 19.6/4.66 & $7 / 52$ & $\begin{array}{l}1048.53 \\
1412.72 \\
1595.81\end{array}$ & $\begin{array}{l}\text { SPDQVDIFK } \\
\text { LVDDVIYEVYGK } \\
\text { EINGDSVPVLMFFK }\end{array}$ & $\begin{array}{l}\text { CG } 4800 \text { : TRANSLATIONALLY } \\
\text { CONTROLLED TUMOR PROTEIN } \\
\text { HOMOLOG (TCTP) }\end{array}$ & 0.29 & 0037874 \\
\hline 9102 & $29.7 / 4.68$ & $11 / 44$ & $\begin{array}{l}1189.66 \\
1229.57 \\
2087.96 \\
2331.19\end{array}$ & $\begin{array}{l}\text { DSTLIMQLLR } \\
\text { YLAEFATGSDR } \\
\text { AAFDDAIAELDTLSEESYK } \\
\text { LGLALNFSVFYYEILNSPDR }\end{array}$ & $\begin{array}{l}\text { 14-3-3 \& EPSILON } \\
\text { (SUPPRESSOR OF Ras 3-9) }\end{array}$ & 0.42 & 0020238 \\
\hline 9106 & $29.1 / 4.74$ & $10 / 30$ & $\begin{array}{l}1229.57 \\
1357.66\end{array}$ & $\begin{array}{l}\text { YLAEFATGSDR } \\
\text { YLAEFATGSDRK }\end{array}$ & 14-3-3 \& EPSILON & 0.41 & 0020238 \\
\hline 9114 & $23.9 / 4.74$ & $11 / 49.1$ & $\begin{array}{l}1434.67 \\
1648.87 \\
2503.21\end{array}$ & $\begin{array}{l}\text { NGFISHDEFSGPK } \\
\text { DOPFTFQLGAGQVIK } \\
\text { FDSSFDRDQPFTFOLGAGQVIK }\end{array}$ & Fkbp 13 & 0.02 & 0010470 \\
\hline 9115 & $24.1 / 4.40$ & $10 / 50.2$ & $\begin{array}{l}1130.56 \\
1233.64 \\
2090.01 \\
2101.01\end{array}$ & $\begin{array}{l}\text { HIASFEAAER } \\
\text { AFGDVTTPQGLK } \\
\text { ELNAFLADNSYISGYTPSK } \\
\text { IEEFEDFVOSVDIAAFNK }\end{array}$ & $\begin{array}{l}\text { ELONGATION FACTOR } 1 \\
\text { \& BETA }\end{array}$ & 0.04 & 0028737 \\
\hline
\end{tabular}


Table 1. Continued

\begin{tabular}{|c|c|c|c|c|c|c|c|}
\hline \multirow{2}{*}{$\begin{array}{l}\text { SSP } \\
\text { no. }\end{array}$} & \multirow[t]{2}{*}{$\mathrm{kDa} / \mathrm{p} /$} & \multirow[t]{2}{*}{$\mathrm{N} / \%^{\mathrm{a})}$} & \multicolumn{2}{|r|}{ MS/MS } & \multirow{2}{*}{$\begin{array}{l}\text { PROTEIN } \\
\text { IDENTIFIED }\end{array}$} & \multirow{2}{*}{$\begin{array}{l}\text { Relative } \\
\text { abun- } \\
\text { dance }\end{array}$} & \multirow{2}{*}{$\begin{array}{l}\text { FLYBASE } \\
\text { Accession } \\
\text { No. }\end{array}$} \\
\hline & & & $\mathrm{MH}^{+}$ & SEQUENCE TAG & & & \\
\hline 9401 & $53.8 / 4.70$ & $24 / 54.4$ & $\begin{array}{l}1095.50 \\
1105.61 \\
1388.73 \\
1507.75 \\
1519.79 \\
1749.85\end{array}$ & $\begin{array}{l}\text { SGSPVEYSGGR } \\
\text { SHLLFFVSR } \\
\text { QLAPIYDQLAEK } \\
\text { SVFEGELNEENLK } \\
\text { VEEGVLVATVDNFK } \\
\text { VDATVEGELAEOYAVR }\end{array}$ & $\begin{array}{l}\text { PROTEIN DISULFIDE } \\
\text { ISOMERASE }\end{array}$ & 0.30 & 0014002 \\
\hline 9402 & $48.6 / 4.75$ & $11 / 29.1$ & $\begin{array}{l}1153.65 \\
1471.72 \\
1654.68\end{array}$ & $\begin{array}{l}\text { RLHVWDLSK } \\
\text { TPSSDVLVFDYTK } \\
\text { SDNAAESFDDAVEER }\end{array}$ & $\begin{array}{l}\text { CHROMATIN ASSEMBLY } \\
\text { FACTOR } 1 \text { SUBUNIT } \\
\text { (Caf 1) }\end{array}$ & 0.16 & 0015610 \\
\hline 9505 & $44.9 / 4.38$ & $11 / 35$ & $\begin{array}{l}974.45 \\
1787.87 \\
2021.05\end{array}$ & $\begin{array}{l}\text { EAQDEVQR } \\
\text { FVLTPGTFYNDAEADK } \\
\text { SGTIFDNVLITDDVELAAK }\end{array}$ & CALRETICULIN & 0.45 & 0005585 \\
\hline
\end{tabular}

a) $\mathbf{N}=$ Number of matched peptides; $\%=$ Coverage of full length protein by tryptic peptides

Table 2. Identification by MALDI-TOF AND MALDI-TOF/TOF MS of basic polypeptides (NEPHGE) recorded in the Drosophila wing imaginal disc database

\begin{tabular}{|c|c|c|c|c|c|c|c|}
\hline \multirow{2}{*}{$\begin{array}{l}\text { SSP } \\
\text { no. }\end{array}$} & \multirow[t]{2}{*}{$\mathrm{kDa} / \mathrm{p} /$} & \multirow[t]{2}{*}{$\mathrm{N} / \%^{\mathrm{a})}$} & \multicolumn{2}{|r|}{$\mathrm{MS} / \mathrm{MS}$} & \multirow{2}{*}{$\begin{array}{l}\text { PROTEIN } \\
\text { IDENTIFIED }\end{array}$} & \multirow{2}{*}{$\begin{array}{l}\text { Relative } \\
\text { abun- } \\
\text { dance }\end{array}$} & \multirow{2}{*}{$\begin{array}{l}\text { FLYBASE } \\
\text { Accession } \\
\text { No. }\end{array}$} \\
\hline & & & $\mathrm{MH}^{+}$ & SEQUENCE TAG & & & \\
\hline 1004 & $17.9 / 8.43$ & $9 / 44.8$ & $\begin{array}{l}1055.52 \\
1183.59 \\
1800.86\end{array}$ & $\begin{array}{l}\text { IESYGSQSGK } \\
\text { KIESYGSQSGK } \\
\text { SIYGNKFPDENFELK }\end{array}$ & CYCLOPHILIN 1 & 3.02 & 0004432 \\
\hline 1102 & 26.9/9.12 & $9 / 38$ & $\begin{array}{l}1198.69 \\
1358.72 \\
1385.74 \\
1757.80\end{array}$ & $\begin{array}{l}\text { AAVVGMTLPIAR } \\
\text { NAVSLVTGGASGLGR } \\
\text { QGASVILADLPSSK } \\
\text { LSAGLMGANEPNODGQR }\end{array}$ & $\begin{array}{l}\text { 3-HYDROXYACYL-CoA } \\
\text { DEHYDROGENASE TYPE II } \\
\text { (SCULLY) }\end{array}$ & 0.46 & 0021765 \\
\hline 1201 & $35.3 / 8.56$ & $10 / 35.5$ & $\begin{array}{l}1369.74 \\
1495.85 \\
1546.82 \\
1763.80\end{array}$ & $\begin{array}{l}\text { GAAONIIPASTGAAK } \\
\text { VPTPNVSVVDLTVR } \\
\text { GTVAAEGGFLVVNGOK } \\
\text { LISWYDNEFGYSNR }\end{array}$ & $\begin{array}{l}\text { GLYCERALDEHYDE-3- } \\
\text { PHOSPATE } \\
\text { DEHYDROGENASE II }\end{array}$ & 1.78 & 0001092 \\
\hline 1202 & $31.5 / 8.88$ & $7 / 27.8$ & $\begin{array}{l}1210.72 \\
1381.68 \\
1766.86 \\
1869.98\end{array}$ & $\begin{array}{l}\text { NVGVITLNRPK } \\
\text { TFHATFSTADRK } \\
\text { EAVNTAYETTLQEGLK } \\
\text { FGOPEIALGTIPGAGGTOR }\end{array}$ & CG 18645 & 0.38 & 0033879 \\
\hline 1302 & $48.1 / 8.69$ & $11 / 24.8$ & $\begin{array}{l}1267.65 \\
1276.58 \\
1370.72 \\
1487.74 \\
1511.78\end{array}$ & $\begin{array}{l}\text { GLYSNPPVHGAR } \\
\text { DHSVYLTNDGR } \\
\text { IAAEILNNEDLR } \\
\text { DDNTQPFVLPSVR } \\
\text { HNVTAQSISGTGALR }\end{array}$ & CG 4233 & 0.09 & 0031380 \\
\hline 1401 & $41.6 / 8.73$ & $11 / 32.4$ & $\begin{array}{l}1085.55 \\
1302.71 \\
1373.72 \\
1450.74 \\
1860.98\end{array}$ & $\begin{array}{l}\text { TAFGTFGGSLK } \\
\text { ITGHLVHELQR } \\
\text { GINQTQLOTTAAK } \\
\text { ERVDEFSLLSQK } \\
\text { LNVNGGAIALGHPLGASGSR }\end{array}$ & $\begin{array}{l}\text { YIPPEE INTERACTING } \\
\text { PROTEIN } 2\end{array}$ & 0.14 & 0040064 \\
\hline
\end{tabular}


Table 2. Continued

\begin{tabular}{|c|c|c|c|c|c|c|c|}
\hline \multirow{2}{*}{$\begin{array}{l}\text { SSP } \\
\text { no. }\end{array}$} & \multirow[t]{2}{*}{$\mathrm{kDa} / \mathrm{p} /$} & \multirow[t]{2}{*}{$\mathrm{N} / \%^{\mathrm{a})}$} & \multicolumn{2}{|r|}{ MS/MS } & \multirow{2}{*}{$\begin{array}{l}\text { PROTEIN } \\
\text { IDENTIFIED }\end{array}$} & \multirow{2}{*}{$\begin{array}{l}\text { Relative } \\
\text { abun- } \\
\text { dance }\end{array}$} & \multirow{2}{*}{$\begin{array}{l}\text { FLYBASE } \\
\text { Accession } \\
\text { No. }\end{array}$} \\
\hline & & & $\mathrm{MH}^{+}$ & SEQUENCE TAG & & & \\
\hline 1404 & $44.6 / 7.84$ & $10 / 26$ & $\begin{array}{l}1155.55 \\
1183.62 \\
1208.59 \\
1312.65 \\
1640.82\end{array}$ & $\begin{array}{l}\text { TELHHFESR } \\
\text { HLHAEHALQK } \\
\text { SFENDLNTLR } \\
\text { EANDPHFQQVK } \\
\text { LVSSGPHSQDFIEPK }\end{array}$ & CG 8507 & 0.11 & 0037756 \\
\hline 2102 & $22.1 / 8.69$ & $11 / 52.7$ & $\begin{array}{l}1104.53 \\
1169.58 \\
1358.66 \\
2004.09\end{array}$ & $\begin{array}{l}\text { QIENSATDAR } \\
\text { FEDENFKLK } \\
\text { DTNGSOFFITTK } \\
\text { DVVIANSGTLPVSEAFSVAK }\end{array}$ & CG 2852 & 1.55 & 0034753 \\
\hline 2203 & $35.3 / 8.25$ & $8 / 26$ & $\begin{array}{l}833.47 \\
1495.84 \\
1546.81 \\
1763.79\end{array}$ & $\begin{array}{l}\text { IGINGFGR } \\
\text { VPTPNVSVVDLTVR } \\
\text { GTVAAEGGFLVVNGQK } \\
\text { LISWYDNEFGYSNR }\end{array}$ & $\begin{array}{l}\text { GLYCERALDEHYDE-3- } \\
\text { PHOSPHATE DEHYDROGENASE }\end{array}$ & 0.13 & 0001091 \\
\hline 2206 & $38.6 / 7.10$ & $15 / 44$ & $\begin{array}{l}1230.62 \\
1317.67 \\
1534.71 \\
1608.84 \\
2148.00\end{array}$ & $\begin{array}{l}\text { VDITDREQVR } \\
\text { YFNPVGAHISGR } \\
\text { FVYSSSATVYGEPK } \\
\text { DYIHIVDLAEGHVK } \\
\text { RPSLSVYGSDFPTHDGTGVR }\end{array}$ & CG 12030 & 0.13 & 0035147 \\
\hline 2401 & $51.5 / 8.89$ & $12 / 27$ & $\begin{array}{l}945.51 \\
1093.67 \\
1439.77 \\
1542.77 \\
1688.86\end{array}$ & $\begin{array}{l}\text { SQVQQLSR } \\
\text { ALGLPIERPK } \\
\text { SGQVVPGYGHAVLR } \\
\text { HLPEDETFQLVSK } \\
\text { ALVTETSVLDADEGIR }\end{array}$ & $\begin{array}{l}\text { CG } 3861 \\
\text { CITRATE SYNTHASE }\end{array}$ & 0.15 & 0026708 \\
\hline 2602 & $57.4 / 7.13$ & $15 / 39$ & $\begin{array}{l}1014.52 \\
1526.82 \\
1690.94 \\
1895.99\end{array}$ & $\begin{array}{l}\text { EPGLGDWLK } \\
\text { LGYEHPVAIALDTK } \\
\text { GVNLPGVPVDLPAVSEK } \\
\text { GAGTIDASHAAAIAAVEAATK }\end{array}$ & PYRUVATE KINASE & 0.73 & 0003178 \\
\hline 2801 & $85.3 / 8.49$ & $26 / 35.3$ & $\begin{array}{l}1170.70 \\
1214.62 \\
1457.81 \\
1625.75 \\
1854.93\end{array}$ & $\begin{array}{l}\text { LNRPLTLSEK } \\
\text { NGSWGGVPDVAR } \\
\text { IPFNVTPGSEQIR } \\
\text { WVAVGDENYGEGSSR } \\
\text { VLYSHLDDPANODIVR }\end{array}$ & ACONITASE & 0.41 & 0010100 \\
\hline 3802 & 103.0/8.14 & $28 / 35.4$ & $\begin{array}{l}1128.63 \\
1205.68 \\
1365.69 \\
1425.81 \\
1526.68 \\
2184.08\end{array}$ & $\begin{array}{l}\text { VTGSPNLATLR } \\
\text { VFFSSIRPPR } \\
\text { TEAIVEFVASGSR } \\
\text { OLVAEGLVLAEQR } \\
\text { YGDITQDDAPEFR } \\
\text { EGRPTAEQOTLIELEDQAR }\end{array}$ & TUDOR - SN & 0.08 & 0035121 \\
\hline 5201 & $30.5 / 6.44$ & $12 / 44$ & $\begin{array}{l}1181.53 \\
1443.73 \\
1461.71 \\
1505.75 \\
1950.87\end{array}$ & $\begin{array}{l}\text { YQLDDDASVR } \\
\text { LTTNNFALGYTTK } \\
\text { LSLEGNFAPOSGNK } \\
\text { VNNASOVGLGYQQK } \\
\text { TSSGIEFNTAGHSNOESGK }\end{array}$ & $\begin{array}{l}\text { VOLTAGE-DEPENDENT } \\
\text { ANION SELECTIVE CHANNEL } \\
\text { (PORIN) }\end{array}$ & 0.19 & 0004363 \\
\hline 5301 & $38.9 / 6.92$ & $11 / 37$ & $\begin{array}{l}1502.71 \\
1658.81 \\
1898.90 \\
2128.10\end{array}$ & $\begin{array}{l}\text { LQDIGVENTEDNR } \\
\text { RLQDIGVENTEDNRR } \\
\text { YVAGSAGAGSGSLFVANHAY } \\
\text { IVPIVEPEVLPDGDHDLDR }\end{array}$ & ALDOLASE & 0.36 & 0000064 \\
\hline 5501 & $43.9 / 7.01$ & $12 / 30$ & $\begin{array}{l}1175.66 \\
1238.58\end{array}$ & $\begin{array}{l}\text { YTLAPVAAELK } \\
\text { IGGSLFDEEGSK }\end{array}$ & PHOSPHOGLYCERATE KINASE & 0.46 & 0003075 \\
\hline
\end{tabular}


Table 2. Continued

\begin{tabular}{|c|c|c|c|c|c|c|c|}
\hline \multirow{2}{*}{$\begin{array}{l}\text { SSP } \\
\text { no. }\end{array}$} & \multirow[t]{2}{*}{$\mathrm{kDa} / \mathrm{p} /$} & \multirow[t]{2}{*}{$\mathrm{N} / \%^{\text {a) }}$} & \multicolumn{2}{|r|}{ MS/MS } & \multirow{2}{*}{$\begin{array}{l}\text { PROTEIN } \\
\text { IDENTIFIED }\end{array}$} & \multirow{2}{*}{$\begin{array}{l}\text { Relative } \\
\text { abun- } \\
\text { dance }\end{array}$} & \multirow{2}{*}{$\begin{array}{l}\text { FLYBASE } \\
\text { Accession } \\
\text { No. }\end{array}$} \\
\hline & & & $\mathrm{MH}^{+}$ & SEQUENCE TAG & & & \\
\hline & & & 1328.74 & LSIENLDLAGKR & & & \\
\hline & & & 1634.78 & LGDVYVNDAFGTAHR & & & \\
\hline & & & 1685.79 & FYVEEEGKGLDASGGK & & & \\
\hline \multirow[t]{6}{*}{7502} & $46.5 / 6.10$ & $19 / 51.0$ & 1100.49 & DGQYDLDFK & ENOLASE & 0.77 & 0000579 \\
\hline & & & 1238.68 & LANLYKEFIK & & & \\
\hline & & & 1471.67 & DGQYDLDFKNEK & & & \\
\hline & & & 1764.92 & AAVPSGASTGVHEALELR & & & \\
\hline & & & 2147.17 & EIILPVPAFNVINGGSHAGNK & & & \\
\hline & & & 2208.07 & FGLDATAVGDEGGFAPNIQSNK & & & \\
\hline \multirow[t]{4}{*}{8601} & $80.4 / 7.56$ & $17 / 23.9$ & 1192.59 & NYLNADVEVR & CG 8256 & 2.66 & 0022160 \\
\hline & & & 1599.81 & IHPEFPYIDAEIR & I(2)K 05713 & & \\
\hline & & & 1668.80 & TALVELDDFASGTSSR & & & \\
\hline & & & 1858.89 & SFGDGDVSGEQLHEILR & & & \\
\hline
\end{tabular}

a) $\mathbf{N}=$ Number of matched peptides; $\%=$ Coverage of full length protein by tryptic peptides 